\title{
Engineering Practice as an Emerging Field of Inquiry: a Historical Overview
}

\section{Mr. Bill E Williams, CEG-IST Universidade de Lisboa}

Bill Williams originally trained as a chemist at the National University of Ireland and went on to work in education in Ireland, UK, Eritrea, Kenya, Mozambique and Portugal. He lectures on technical communication at the Instituto Politécnico de Setúbal and is a member of the CEG-IST, Universidade de Lisboa research centre.

\section{Prof. Jose Figueiredo, IST, Universidade de Lisboa}

$\mathrm{PhD}$ in Industrial Engineering and Management "Sociotechnical approaches to inter-institutional Information Systems design", IST, Technical University of Lisbon, MBA in Information Management at UCP (Portuguese Catholic University - Lisbon), Engineer Degree in Electronics and Digital Systems (Coimbra University). Current Professor at the Engineering and Management Department of IST (Engineering school of Universidade de Lisboa) 


\title{
Engineering practice as an emerging field of inquiry: a historical overview
}

\begin{abstract}
:
Perception of the nature of engineering practice is an aspect of technology literacy of direct interest to engineering educators, one that impacts a variety of actors: potential and present engineering students, engineering faculty and the general public. This paper contributes to scholarship in the areas of technology literacy and engineering practice studies by presenting a timeline of empirical studies of engineering practice carried out in the US, Europe and Australia from the $19^{\text {th }}$ century to today. We observe a notable widening of the range of research approaches employed to capture what engineers do and an increasing recognition that sociotechnical aspects of engineering work play an important role in the workplace. We conclude by setting out some implications for educators of the empirical findings from of this area of scholarship.
\end{abstract}

\section{Context}

At a symposium entitled Engineering as a Social Enterprise organized by the US National Academy of Engineering in 1990, Walter Vincenti pointed out that "engineering functions inseparably from the society of which it is part" and he went on to suggest that "to perform engineering's task as a social enterprise" engineering practice needed to be better understood (Sladovitch 1991, p. 2 - 4). In the intervening years there has been a growing body of empirical data about this topic. Thus the nature of interactions taking place in enterprises between engineers themselves and interaction with other colleagues and with clients have been a focus of study (Barley, 2005; Bailey and Barley, 2010; Bucciarelli, 2003; Vinck, 2003; Faulkner 2007; Downey 1998). Trevelyan (2013) gathered data on engineers working in Australia and SE Asia and concluded that sociotechnical aspects of engineering work such as technical coordination are essential features of successful engineering performance and require skills that go well beyond the traditional engineering science competences espoused in the Grinter Report (1955). Nevertheless as will be shown later as this research has been dispersed in a variety of fields such as organization science, engineering studies, sociology, anthropology and ethnography it has been difficult to arrive at a global portrait of what engineers do.

There has simultaneously been an increasing awareness of the need for engineering practice to more effectively inform the practice of education and training. The ASEE has taken a lead in this process and we note that its Transforming Undergraduate Education in Engineering program has underlined the importance of developing a new strategy for undergraduate engineering education to meet the needs of engineering of industry in the $21^{\text {st }}$ century (ASEE, 2013).

\section{Research Question}

What insights can a timeline approach to the evolution of engineering practice research provide? The question is of an exploratory nature and can be classified as an example of the US National Research Council's category of Description-what is happening (National Research Council, 2002, p. 70) 


\section{Engineering Practice - An Emerging Field of Study}

Peter Fensham (2004) published a framework with which to judge the evolution and maturity of science education research. It involves 14 criteria which are grouped into three broad categories: structural, research, and outcome as shown in Table 1.

TABLE 1: FENSHAM'S CRITERIA FOR SCIENCE EDUCATION RESEARCH EVOLUTION

\begin{tabular}{|l|l|}
\hline Category & Criteria \\
\hline Structural & Academic recognition, Research journals, Professional associations, Research conferences, Research centres, Research training; \\
\hline Research & $\begin{array}{l}\text { Scientific knowledge, Asking questions, Conceptual and theoretical development, Research Methodologies, Progression, } \\
\text { Model publications, Seminal publications; }\end{array}$ \\
\hline Outcome & Implications for practice \\
\hline
\end{tabular}

This framework was adopted by Froyd and Lohman (2010) to argue that engineering research has become an established field and they supported this claim by presenting a detailed timeline of research in the field from 1973 onwards. Later Williams (2015, pp 87-90) adopted the Fensham framework and marshalled data to claim that engineering practice was poised to emerge as a field of inquiry. He detailed research criteria from the framework which were being satisfied although he observed that as yet there is little evidence to support a claim that structural criteria were being met in this area of research.

Williams (2015) compiled a timeline of notable empirical research in the field of engineering practice and this study complements his argument and provides scholars and engineering professionals with an opportunity to consider the strength of the claim. At the same time, a study of the findings and the trends revealed in the empirical research thus captured chronologically provides useful pointers as to how this field of inquiry can contribute to decision making by engineering educators and trainers.

\section{Timeline of empirical studies}

Preliminary note: The timeline below aims for representativeness rather than completion. Although many of the scholars cited have been responsible for numerous contributions to the field, to facilitate the reading and interpretation of the chronology we have limited ourselves to providing just one contribution from each of the authors cited; additional work is cited in the contributions/findings column in some cases. 


\begin{tabular}{|c|c|c|c|c|}
\hline \multirow[t]{2}{*}{ YEAR } & \multicolumn{3}{|c|}{ PUBLICATION } & \multirow[t]{2}{*}{ CONTRIBUTION/FINDINGS } \\
\hline & Book & Journal article/ book chapter & Report & \\
\hline 1911 & $\begin{array}{l}\text { Taylor, F. W., The } \\
\text { Principles of Scientific } \\
\text { Management, New } \\
\text { York, NY, USA and } \\
\text { London, UK: Harper \& } \\
\text { Brother }\end{array}$ & & & $\begin{array}{l}\text { Scientific management approach proposed } \\
\text { for industrial processes }\end{array}$ \\
\hline 1917 & \begin{tabular}{|l|} 
Fayol, \\
H., Administration \\
industrielle et \\
générale; prévoyance, \\
organisation, \\
commandement, \\
coordination, \\
controle, Paris, H. \\
Dunod et E. Pinat,
\end{tabular} & & & $\begin{array}{l}\text { Industrial management proposals for the } \\
\text { mining industry }\end{array}$ \\
\hline 1933 & $\begin{array}{l}\text { Mayo, E. The human } \\
\text { problems of an } \\
\text { industrial civilization, } \\
\text { Cambridge, MA: } \\
\text { Harvard. }\end{array}$ & & & $\begin{array}{l}\text { Research led by Mayo into productivity in } \\
\text { spinning mills and other industrial contexts } \\
\text { in the Hawthorne Studies was an early } \\
\text { example of observation studies in the } \\
\text { manufacturing workplace }\end{array}$ \\
\hline 1960 & $\begin{array}{l}\text { Barnes L. B., } \\
\text { Organizational } \\
\text { Systems and } \\
\text { Engineering Groups, } \\
\text { Harvard School of } \\
\text { Business, Cambridge } \\
\text { Mass. }\end{array}$ & & & $\begin{array}{l}\text { Suggested innovation is dependent on } \\
\text { organizational structure }\end{array}$ \\
\hline 1961 & $\begin{array}{l}\text { Burns T. and Stalker } \\
\text { G., The Management } \\
\text { of Innovation, } \\
\text { Tavistock, London }\end{array}$ & & & $\begin{array}{l}\text { Suggested R\&D staff had difficulty } \\
\text { communicating with manufacturing dept. }\end{array}$ \\
\hline 1961 & & & \begin{tabular}{|l|} 
Langton, N., The \\
Teaching of \\
Theoretical Subjects \\
to Students of High \\
Polymer \\
Technology. 2 Vols. \\
A Report to the \\
Nuffield \\
Foundation. London
\end{tabular} & $\begin{array}{l}\text { Collected detailed descriptions of the } \\
\text { techniques, processes, instrumentation, } \\
\text { and design procedures used by firms } \\
\text { through interview and brief observation of } \\
\text { polymer technologists and derived a } \\
\text { theoretical curriculum. }\end{array}$ \\
\hline 1966 & & $\begin{array}{l}\text { LeBold, W. K., Perrucci, R. and Howland, } \\
\text { W. E., 'The Engineer in Industry and } \\
\text { Government," Journal of Engineering } \\
\text { Education, vol. 56, no. 7, March 1966, pp. } \\
\text { 237-273. }\end{array}$ & & $\begin{array}{l}\text { Reported that in the } 1930 \text { 's in the US three } \\
\text { fifths of engineers under } 40 \text { were occupied } \\
\text { with administrative rather than technical } \\
\text { work according to National Science } \\
\text { Foundation statistical data }\end{array}$ \\
\hline 1969 & $\begin{array}{l}\text { Turner, B. T, } \\
\text { Management } \\
\text { Training for } \\
\text { Engineers. London, } \\
\text { Business Books }\end{array}$ & & & $\begin{array}{l}\text { Engineers at English Electric; }>50 \% \text { of work } \\
\text { time involved interaction and } \\
\text { communication }\end{array}$ \\
\hline 1970 & & $\begin{array}{l}\text { Heywood, J., Qualities and their assess- } \\
\text { ment in the education of technologists. } \\
\text { International Bulletin of Mechanical } \\
\text { Engineering Education, 9, 15-29 }\end{array}$ & & $\begin{array}{l}\text { Role analysis of steelworks managers; } \\
\text { enabled William Humble of the British } \\
\text { Steel Corporation to propose a Taxonomy } \\
\text { of Educational Objectives of managers }\end{array}$ \\
\hline
\end{tabular}




\begin{tabular}{|c|c|c|c|c|}
\hline \multirow[t]{2}{*}{ YEAR } & \multicolumn{3}{|c|}{ PUBLICATION } & \multirow[t]{2}{*}{ CONTRIBUTION/FINDINGS } \\
\hline & Book & Journal article/ book chapter & Report & \\
\hline & & & \begin{tabular}{|l|} 
Venning, M. \\
Professional \\
Engineers, Scientists \\
and Technologists in \\
the Engineering \\
Industry, EUITB \\
Research Report no. \\
4, Watford, \\
Engineering \\
Industry Training \\
Board
\end{tabular} & $\begin{array}{l}\text { Studied around } 1000 \text { engineers; noted } \\
52 \% \text { of work time involved interaction and } \\
\text { communication }\end{array}$ \\
\hline 1983 & $\begin{array}{l}\text { Hutton, S. P and P. } \\
\text { Lawrence The work } \\
\text { of production } \\
\text { managers: case } \\
\text { Studies at } \\
\text { Manufacturing } \\
\text { Companies in the } \\
\text { United Kingdom. } \\
\text { University of } \\
\text { Southampton }\end{array}$ & & & $\begin{array}{l}\text { Compared German and British production } \\
\text { managers }\end{array}$ \\
\hline 1987 & $\begin{array}{l}\text { Latour, B., Science in } \\
\text { Action: How to } \\
\text { Follow Scientists and } \\
\text { Engineers Through } \\
\text { Society. Milton } \\
\text { Keynes: Open } \\
\text { University Press }\end{array}$ & & & $\begin{array}{l}\text { Applied Actor Network Theory to the } \\
\text { field of Science and Technology Studies }\end{array}$ \\
\hline 1987 & & $\begin{array}{l}\text { Law, J., Technology and } \\
\text { Heterogeneous Engineering: The Case } \\
\text { of Portuguese Expansion, in: Bijker, } \\
\text { W.E., Hughes, T.P. \& Pinch, T.J. } \\
\text { (Eds.) The Social Construction of } \\
\text { Technological Systems: New Directions } \\
\text { in the Sociology and History of } \\
\text { Technology. Cambridge, MA, MIT Press }\end{array}$ & & $\begin{array}{l}\text { Proposed the heterogeneous } \\
\text { engineering concept to characterize a } \\
\text { proposed network of actors involved in } \\
\text { use of maritime technology in the XV } \\
\text { century }\end{array}$ \\
\hline 1991 & $\begin{array}{l}\text { Sladovich, H., (ed.) } \\
\text { (1991) Engineering } \\
\text { as a social } \\
\text { enterprise, National } \\
\text { Academy Press, } \\
\text { Washington, D.C. } \\
\end{array}$ & & & $\begin{array}{l}\text { Set out sociotechnical aspects of } \\
\text { engineering in the context of the } \\
\text { relationship between engineering and } \\
\text { society }\end{array}$ \\
\hline 1994 & $\begin{array}{l}\text { Gibbons, M., } \\
\text { Limoges C., Nowotny } \\
\text { H., Schwartzman S., } \\
\text { Scott, P \& Trow M. } \\
\text { The new production } \\
\text { of knowledge: The } \\
\text { Dynamics of Science } \\
\text { and Research in } \\
\text { Contemporary } \\
\text { Societies, Sage } \\
\text { Publications, London }\end{array}$ & & & $\begin{array}{l}\text { Proposed Mode } 1 \text { and Mode } 2 \text { models to } \\
\text { characterize engineering knowledge } \\
\text { production in academia and in industry } \\
\text { respectively. See Shinn (2002) for a } \\
\text { critique of this approach. }\end{array}$ \\
\hline
\end{tabular}




\begin{tabular}{|c|c|c|c|c|}
\hline YEAR & & PUBLICATION & & CONTRIBUTION/FINDINGS \\
\hline & Book & Journal article/ book chapter & Report & \\
\hline 1994 & $\begin{array}{l}\text { Bucciarelli, L. L. } \\
\text { Designing Engineers, } \\
\text { Cambridge, MA, MIT } \\
\text { Press }\end{array}$ & & & $\begin{array}{l}\text { Suggested that engineering design is a } \\
\text { social process that involves constant } \\
\text { negotiation among many parties }\end{array}$ \\
\hline 1996 & & $\begin{array}{l}\text { Etzkowitz, H \& Leydesdorff, L. } \\
\text { Emergence of a Triple Helix of } \\
\text { University-Industry-Government } \\
\text { Relations. Science and Public Policy, 23, } \\
\text { 279-86 }\end{array}$ & & $\begin{array}{l}\text { Proposed the Triple Helix model of } \\
\text { University-Industry-Government } \\
\text { Relations. See Shinn (2002) for a critique } \\
\text { of this approach. }\end{array}$ \\
\hline 1996 & & $\begin{array}{l}\text { Vest D., Long M. \& Anderson T., } \\
\text { Electrical Engineers' Perceptions of } \\
\text { Communication Training and Their } \\
\text { Recommendations for Curricular } \\
\text { Change: Results of a National Survey, } \\
\text { IEEE Transactions On Professional } \\
\text { Communication, Vol. 39, No. 1, March } \\
1996\end{array}$ & & Study of US-based electrical engineers \\
\hline 1996 & & $\begin{array}{l}\text { Regan, T. M., \& Schmidt, J. A. (1999, } \\
\text { November). Student learning } \\
\text { outcomes: alumni, graduating seniors } \\
\text { and incoming freshmen. In Frontiers in } \\
\text { Education Conference, 1999. FIE'99. } \\
\text { 29th Annual (Vol. 3, pp. 13A5-16). IEEE. }\end{array}$ & & $\begin{array}{l}\text { Presented data from alumni studies. } \\
\text { There have been a number of such } \\
\text { studies (Puerzer \& Rooney, 2002; } \\
\text { Besterfield-Sacre, M., Shuman, L., Wolfe, } \\
\text { H., \& McGourty, J., 2000) and in the US } \\
\text { they have frequently been employed as } \\
\text { an instrument to monitor ABET } \\
\text { competence compliance (Passow, H. J., } \\
\text { 2012). }\end{array}$ \\
\hline 1997 & & $\begin{array}{l}\text { Kilduff M., Funk J.L \&. Mehra, A. 1997, } \\
\text { "Engineering Identity in a Japanese } \\
\text { Factory", Organization Science, Vol. 8, } \\
\text { No. 6, pp. 579-592 }\end{array}$ & & $\begin{array}{l}\text { Intensive observation of } 11 \text { Japanese } \\
\text { engineers over an } 11 \text {-month period. }\end{array}$ \\
\hline 1998 & $\begin{array}{l}\text { Downey, G L. } 1998 . \\
\text { The machine in me: } \\
\text { An anthropologist } \\
\text { sits among } \\
\text { computer } \\
\text { engineers. New } \\
\text { York: Routledge }\end{array}$ & & & $\begin{array}{l}\text { Looked at engineering practice through } \\
\text { an anthropological lens }\end{array}$ \\
\hline 1999 & $\begin{array}{l}\text { Rodrigues, M de L., } \\
\text { 1999, Os } \\
\text { Engenheiros em } \\
\text { Portugal, Celta } \\
\text { Editora, Oeiras }\end{array}$ & & & $\begin{array}{l}\text { A sociological study, sponsored by the } \\
\text { Portuguese Order of Engineers, } \\
\text { involving a survey of over 10,000 } \\
\text { engineers in Portugal and interviews } \\
\text { with } 141\end{array}$ \\
\hline 2000 & & $\begin{array}{l}\text { Sandberg J. (2000) Understanding } \\
\text { human competence at work: an } \\
\text { interpretative approach, Academy of } \\
\text { Management Journal, 2000, vol. 93, } \\
\text { N0. 1, 9-25 }\end{array}$ & & $\begin{array}{l}\text { Noted } 3 \text { different conceptions of Volvo } \\
\text { engine optimizers and how this affected } \\
\text { their work practice }\end{array}$ \\
\hline 2001 & $\begin{array}{l}\text { Evans, A. G. T. } \\
\text { (2001). C. Y. } \\
\text { O'Connor: His Life } \\
\text { and Legacy, } \\
\text { University of } \\
\text { Western Australia } \\
\text { Press. }\end{array}$ & & & $\begin{array}{l}\text { Case study of a pioneering engineer in } \\
19^{\text {th }} \text { century Australia }\end{array}$ \\
\hline
\end{tabular}




\begin{tabular}{|c|c|c|c|c|}
\hline \multirow[t]{2}{*}{ YEAR } & \multicolumn{3}{|c|}{ PUBLICATION } & \multirow{2}{*}{$\begin{array}{c}\text { CONTRIBUTION/FINDINGS } \\
\text { Book }\end{array}$} \\
\hline & Book & Journal article/ book chapter & & \\
\hline 2002 & $\begin{array}{l}\text { Williams, R., } \\
\text { Retooling: } A \\
\text { Historian Confronts } \\
\text { Technological } \\
\text { Change. } \\
\text { Cambridge, MA, } \\
\text { USA, MIT Press }\end{array}$ & & & $\begin{array}{l}\text { Historical analysis of the evolution of } \\
\text { MIT; described the "expansive } \\
\text { disintegration" of engineering }\end{array}$ \\
\hline 2003 & $\begin{array}{l}\text { Vinck, D. Everyday } \\
\text { Engineering: An } \\
\text { Ethnography of } \\
\text { Design and } \\
\text { Innovation. Boston, } \\
\text { MA, MIT Press } \\
\end{array}$ & & & $\begin{array}{l}\text { Engineering design seen through an } \\
\text { ethnographic lens }\end{array}$ \\
\hline 2006 & & $\begin{array}{l}\text { Jonassen D.; Strobel J.; Lee C. B., } \\
\text { Everyday Problem Solving in } \\
\text { Engineering: Lessons for Engineering } \\
\text { Educators, Journal of Engineering } \\
\text { Education; Apr 2006; 95, } 2 \text {. }\end{array}$ & & $\begin{array}{l}\text { Qualitative study of workplace } \\
\text { engineering problems identified that } \\
\text { workplace problems are ill-structured } \\
\text { and complex because they possess } \\
\text { conflicting goals, multiple solution } \\
\text { methods, non-engineering success } \\
\text { standards, non-engineering constraints, } \\
\text { unanticipated problems, distributed } \\
\text { knowledge, collaborative activity } \\
\text { systems }\end{array}$ \\
\hline 2007 & $\begin{array}{l}\text { Mukerji, C., } \\
\text { Impossible } \\
\text { Engineering: } \\
\text { Technology and } \\
\text { Territoriality on the } \\
\text { Canal du Midi. } \\
\text { Princeton: } \\
\text { Princeton } \\
\text { University Press }\end{array}$ & & & $\begin{array}{l}\text { Case study of French engineering in the } \\
17 \text { th century }\end{array}$ \\
\hline 2007 & & $\begin{array}{l}\text { Faulkner, W. Nuts and Bolts and } \\
\text { People. Social Studies of Science, } 37 \text { (3), } \\
\text { 331-356. }\end{array}$ & & Study of women in engineering \\
\hline 2009 & & & $\begin{array}{l}\text { Frost \& Sullivan } \\
\text { Whitepaper: } \\
\text { Meetings Around } \\
\text { the World II: } \\
\text { Charting the } \\
\text { Course of } \\
\text { Advanced } \\
\text { Collaboration, } \\
\text { Frost \& Sullivan, } \\
\text { Silicon Valley }\end{array}$ & $\begin{array}{l}\text { A global study of business performance } \\
\text { concluded that collaboration contributed } \\
\text { twice the impact of a company's } \\
\text { strategic orientation and more than five } \\
\text { times the impact of market and } \\
\text { technological turbulence influences. See } \\
\text { also Gofus, } 2006\end{array}$ \\
\hline
\end{tabular}




\begin{tabular}{|c|c|c|c|c|}
\hline \multirow[t]{2}{*}{ YEAR } & \multicolumn{3}{|c|}{ PUBLICATION } & \multirow[t]{2}{*}{ CONTRIBUTION/FINDINGS } \\
\hline & Book & Journal article/ book chapter & Report & \\
\hline 2011 & & $\begin{array}{l}\text { Bailey, D. E. \& Barley, S. R., Teaching- } \\
\text { Learning Ecologies: Mapping the En- } \\
\text { vironment to Structure Organization } \\
\text { Science, } 22 \text { (1), 262-285. }\end{array}$ & & $\begin{array}{l}\text { Presented observational field data } \\
\text { showing difference in learning of } \\
\text { structural engineers and hardware } \\
\text { engineers }\end{array}$ \\
\hline 2012 & & $\begin{array}{l}\text { Blandin, B. The Competence of an } \\
\text { Engineer and how it is Built through an } \\
\text { Apprenticeship Program: a Tentative } \\
\text { Model. International Journal of } \\
\text { Engineering Education, 28(1), 57-71. } \\
\text { doi: 0949-149X/ }\end{array}$ & & $\begin{array}{l}\text { Empirical data from a study of } \\
\text { apprentice engineers in France whose } \\
\text { conclusions support the findings of the } \\
\text { Trevelyan research in Australia }\end{array}$ \\
\hline 2012 & & $\begin{array}{l}\text { Nielsen K. \& Heymann M., Winds of } \\
\text { change: communication and wind } \\
\text { power technology development in } \\
\text { Denmark and Germany from } 1973 \text { to } \\
\text { ca. 1985, Engineering Studies Vol. 4, } 1\end{array}$ & & $\begin{array}{l}\text { Comparative case study which showed } \\
\text { how engineers' communication with the } \\
\text { public can influence take- up of new } \\
\text { technology. Published in a special issue } \\
\text { of Engineering Studies devoted to } \\
\text { engineers and communication }\end{array}$ \\
\hline 2013 & & $\begin{array}{l}\text { Korte, R., \& Lin, S. Getting on } \\
\text { board: Organizational socialization and } \\
\text { the contribution of social capital. } \\
\text { Human relations, 66(3) }\end{array}$ & & $\begin{array}{l}\text { Studied the role of socialization during } \\
\text { the initial years of engineering } \\
\text { graduates' professional experience }\end{array}$ \\
\hline 2013 & & & $\begin{array}{l}\text { TUEE, 2013, } \\
\text { Transforming } \\
\text { Undergraduate } \\
\text { Education in } \\
\text { Engineering, } \\
\text { Phase } 1 \text { Report, } \\
\text { ASEE, 2013 }\end{array}$ & $\begin{array}{l}\text { ASEE's Executive Director Norman } \\
\text { Fortenberry subsequently called on } \\
\text { practicing engineers to engage with } \\
\text { faculty on their research activities as this } \\
\text { would help academics to "build-in } \\
\text { learning experiences to emulate real- } \\
\text { world practice" (2014) }\end{array}$ \\
\hline 2013 & $\begin{array}{l}\text { Williams B., } \\
\text { Figueiredo J. \& } \\
\text { Trevelyan J. (Eds), } \\
\text { Engineering } \\
\text { Practice in a Global } \\
\text { Context: } \\
\text { Understanding the } \\
\text { Technical and the } \\
\text { Social, CRCPress, } \\
\text { Taylor \& Francis, } \\
\text { September }\end{array}$ & & & $\begin{array}{l}\text { Presented empirical data on the } \\
\text { sociotechnical dimension of engineering } \\
\text { practice based on studies in } 7 \text { countries }\end{array}$ \\
\hline 2014 & & $\begin{array}{l}\text { Baudrin et al., On n'est pas des cow- } \\
\text { boys Controverse sur l'exploitation des } \\
\text { gaz de schiste et stratégie de l'industrie } \\
\text { pétrolière, Revue d'anthropologie des } \\
\text { connaissances, } 2014 / 2 \text { Vol. } 8, n^{\circ} 2, \text { p. } \\
\text { 451-478. DOI : } 10.3917 / \text { rac. } 023.0451\end{array}$ & & $\begin{array}{l}\text { Study of shale-gas exploration policy in a } \\
\text { one of two special issues of the Revue } \\
\text { d'anthropologie des connaissances } \\
\text { devoted to engineering practice }\end{array}$ \\
\hline 2014 & & $\begin{array}{l}\text { Stevens R., Johri, A. \& O'Connor, K. } \\
\text { Professional Engineering Work, in In } \\
\text { Johri BM \& Olds (eds.), Cambridge } \\
\text { Handbook of Engineering Education } \\
\text { Research, Cambridge University Press, } \\
\text { 2014, New York, NY }\end{array}$ & & $\begin{array}{l}\text { Comprehensive review of engineering } \\
\text { practice research }\end{array}$ \\
\hline
\end{tabular}




\section{Discussion}

The timeline in section 5 allows us to identify a number of phases in the evolution of research in the field of inquiry:

The work published early in the 20th century can be seen as having a precursor role in that it focused on improving industrial productivity and did not tend to focus on engineers in particular. The 60 s and 70s saw the application of statistical methods to study and categorize the workplace practice of engineers. During the 80 s there was an increase in interest in engineering practice by sociologists and the application of actor network theory to describe it. The macro views encapsulated in the Gibbons model and the Triple Helix model of engineering practice and its relation to society, although neither was directly based on empirical data, were widely debated in the $90 \mathrm{~s}$.

The 90s also saw an increasing use of alumni surveys as an instrument to measure the match between competences acquired at university and those needed in the workplace. We note an growing use of qualitative methods to gather empirical data relating to engineering design processes and to sociotechnical aspects of engineering; these included methodologies drawn from fields such as organization science, sociology, anthropology and ethnography. This is an important development because the self-reported perceptions of alumni surveys on their own are somewhat limited in their characterization of what goes on in the workplace and the instruments developed by social and organization scientists can provide a considerably richer picture of what engineers do.

\section{Implications for Engineering Educators and Trainers}

The contours of engineering workplace practice which have been taking shape in the emerging field described in the previous section have implications for engineering education: present courses tend to favour an engineering science approach and do not give attention to the development of competencies that provide value for a firm employing young engineers such as skills in negotiating the socio-technical aspects of workplace practice, effective coordination and communication skills and experience in tackling complex ill-structure problems (Bucciarelli, 2003, Trevelyan 2010, Jorgensen 2007, Korte et al. 2008, Martin 2005).

As Korte and his colleagues have pointed out recent engineering graduates often start with lowlevel, low-risk assignments which firms described as a method to orient the newcomer to work (Korte et al 2008). Indeed various studies have suggested that novice engineers may take around two years to contribute significant to value to a company ${ }^{1}$.

It is now becoming more widely accepted that the engineering workplace typically calls for solutions to "fuzzy" or ill-structured questions (Jonassen et al. al., 2006 p. 146, Nagel et al., 2012) and that these solutions usually involve negotiation with a variety of other actors (Williams \& Figueiredo, 2013). Hence, providing contexts for engineering students to develop and practice such skills and for instructors to assess their acquisition is a major challenge facing those involved with engineering education and training today. Furthermore, given recent advances in the areas of IT simulation tools and in augmented computing, it would seem that Bucciarelli's proposals (2003) regarding the harnessing of the power of online technology could

\footnotetext{
${ }^{1} 1$ See for example Tilli and Trevelyan (2008): “An underlying assumption that has informed our thinking about engineering work is that training and experience is an essential component of the first few years of an engineering career. This assumption is based on data from the framework study interviews in which all participants said that it took between two and five years for a novice to become 'competent'. While each participant had a different interpretation of competence, all identified this early career period as important";
} 
now be put into effect so as to allow simulation of individual and group role-play activities which would both enable engineering students and trainees to acquire and practice these skills. It would also allow instructors to approximate the kind of performance-based assessment which is increasingly being applied in professions such as medicine and aeronautics but in engineering is still quite rare (Nakamura et al., 2011).

This is very much in line with the proposals in the Phase 1 Report of the Transforming Undergraduate Education in Engineering strategy of the ASEE (ASEE, 2013) as one of the key steps it has identified is "to solicit, distil and share the views of the engineering community (...) with respect to future visions for engineering education appropriate to the full spectrum of challenges and opportunities faced by practicing engineers in a variety of operational contexts" (ASEE, 2013). The authors would suggest that these views would be very much enriched if allied with empirical data on the reality of practicing engineers and that such an evidence-based approach has begun to be feasible. Although such data tend to be dispersed, there are now signs of a growing recognition of the need to bring the empirical data and associated research paradigms together so as to better inform management practice and to contribute to more effective engagement between engineering practitioners and faculty. This would help to address the need identified by ASEE Executive Director Norman Fortenberry to "build-in learning experiences to emulate real-world practice" and would also contribute towards what he identifies as an important takeaway from the Phase 1 Report, namely for "practicing engineers to engage with faculty on their research activities" (Fortenberry, 2014). We would suggest, therefore, that the engagement process would be facilitated by the recognition of engineering practice as a field of research as this has the potential to contribute a solid evidence-based platform for practitionereducator involvement.

\section{Conclusion}

In this paper we have used a timeline approach to portray developments in the evolution of engineering practice as an emerging field of study and we note the wide range of research approaches now available to those studying engineering practice. In addition we have pointed out some of the implications for engineering educators and suggested that recent developments in the digital technology could provide the tools for workplace simulation which would emulate the complex decision-making processes which professional engineers routinely face.

The authors believe that by providing a broader perspective on the empirical data which has been accumulating with respect to engineering practice and by showing that there is a growing body of theoretical understanding of such processes that we can contribute to this emerging field and facilitate insights into where future research need to be carried out.

In other words, we hope to have demonstrated in this paper that in the two decades since Vincenti's words at the National Academy of Engineering symposium there has been significant progress in understanding engineering practice, albeit in widely dispersed disciplinary studies, and that this is an emerging area of study which can make an important contribution to decisions about knowledge and skill development of engineering professionals and to the training of future engineers.

\section{References}

ASEE, 2013, Transforming Undergraduate Education in Engineering, Phase 1 Report, 2013

Bailey, D. E., \& Barley, S. (2010). Teaching-Learning Ecologies: Mapping the Environment to Structure Through Action. Organization Science Articles in Advance, 1-25.

Barley, S. R. (2005). What we know (and mostly don't know) about technical work. In S. Ackroyd, R.Batt, P. Thompson \& P. S. Tolbert (Eds.), The Oxford Handbook of Work and Organization (pp. 376-403). Oxford: Oxford University Press

Barnes L. B. (1960), Organizational Systems and Engineering Groups, Harvard School of Business, Cambridge Mass. 
Baudrin et al., On n'est pas des cow-boys Controverse sur l'exploitation des gaz de schiste et stratégie de l'industrie pétrolière, Revue d'anthropologie des connaissances, 2014/2 Vol. 8, n 2, p. 451-478. DOI : 10.3917/rac.023.0451

Besterfield-Sacre, M., Shuman, L., Wolfe, H., \& McGourty, J. (2000). Triangulating assessments: multi-source

feedback systems and closed form surveys. in ASEE Annual Conference proceedings St. Louis, Missouri, 2000.

Blandin, B. (2012). The Competence of an Engineer and how it is Built through an Apprenticeship Program: a Tentative Model. International Journal of Engineering Education, 28(1), 57-71. doi: 0949-149X/9

Bucciarelli, L.L. (1994), "Designing Engineers," Inside Technology, W.E. Bijker, W.B. Carlson, and T.J. Pinch (eds.), Cambridge, MA: MIT Press, 1994.

Bucciarelli, L. L. Bucciarelli, 2003. Designing and learning: a disjunction in contexts. Design Studies, 24(3):295-311

Burns T. and Stalker G., (1961), The Management of Innovation, Tavistock, London

Downey, G L. 1998. The machine in me: An anthropologist sits among computer engineers. New York: Routledge

Etzkowitz, H., \& Leydesdorff, L. (1995). The Triple Helix, University-Industry-Government Relations: A Laboratory for Knowledge Based Economic Development. EASST Review 14, 14-19.

Evans, A. G. T. (2001). C. Y. O'Connor: His Life and Legacy, University of Western Australia Press.

Faulkner, W. (2007). Nuts and Bolts and People. Social Studies of Science, 37(3), 331-356.

Fayol, H., Administration industrielle et générale; prévoyance, organisation, commandement, coordination, controle, Paris, H. Dunod et E. Pinat,

Fensham, P.J., Defining an Identity: The Evolution of Science Education as a Field of Research, Dordrecht, Netherlands: Kluwer Academic Publishers, 2004.

Fortenberry, N., Engineering Education Reform, video interview published on the American Society of Civil Engineers website, accessed 14 May $2014 \mathrm{https} / /$ www.youtube.com/watch?v=Jf9Dk0Atlvw

Frost \& Sullivan Whitepaper (2009) Meetings Around the World II: Charting the Course of Advanced Collaboration, Frost \& Sullivan, Silicon Valley

Froyd, J. E. \& Lohmann, J. R., (2010). Chronological and ontological development of engineering education as a field of inquiry . Proceedings of the Study on the Status, Contributions, and Future Directions of Discipline Based Education Research (DBER), Board on Science Education, National Academies of Science, Washington, DC.

Gibbons, M., Limoges C., Nowotny H., Schwartzman S., Scott, P \& Trow M. (1994) The new production of knowledge: The Dynamics of Science and Research in Contemporary Societies', Sage Publications, London

Gofus N., Conway S., Kostner J., Cotton, Meetings around the World: The Impact of Collaboration on Business Performance. Frost \& Sullivan Whitepaper, Frost \& Sullivan, 2006.

Grinter, L. E. (1955). Report of the Committee on Evaluation of Engineering Education (Grinter Report).

Journal of Engineering Education, 44(3), 25-60.

Heywood, J., (1970) Qualities and their assessment in the education of technologists. International Bulletin of Mechanical Engineering Education, 9, 15-29

Hutton, S. P and P. Lawrence (1982) The work of production managers: case Studies at Manufacturing Companies in the United Kingdom. Southampton: University of Southampton

Jonassen, D., Strobel, J., \& Lee, C. B. (2006). Everyday Problem Solving in Engineering: Lessons for Engineering Educators. Journal of Engineering Education, 95(2), 139-151.

Kilduff M., Funk J.L \&. Mehra, A. 1997, "Engineering Identity in a Japanese Factory", Organization Science, Vol. 8, No. 6, pp. 579-592.

Korte, R. F., Sheppard, S. D., \& Jordan, W. (2008, June 22-26). A Qualitative Study of the Early Work Experiences of Recent Graduates in Engineering. Paper presented at the American Society for Engineering Education, Pittsburgh

Langton, N., (1961) The Teaching of Theoretical Subjects to Students of High Polymer Technology. 2 Vols. A Report to the Nuffield Foundation. London

Law J. (1987). "Technology and Heterogeneous Engineering: The Case of Portuguese Expansion." in W.E. Bijker, T.P. Hughes, and T.J. Pinch (eds.), The Social Construction of Technological Systems: New Directions in the Sociology and History of Technology (Cambridge, MA: MIT Press). 
Latour, B. (1987). Science in Action: How to Follow Scientists and Engineers Through Society. Milton Keynes: Open University Press.

LeBold, W. K., Perrucci, R. and Howland, W. E., (1966) 'The Engineer in Industry and Government," Journal of Engineering Education, vol. 56, no. 7, March 1966, pp. 237-273.

Martin, R., Maytham, B., Case, J., \& Fraser, D. (2005). Engineering graduates' perceptions of how well they were prepared for work in industry. European Journal of Engineering Education, 30(2), 167-180.

Mayo, E. The human problems of an industrial civilization, Cambridge, MA: Harvard

Mukerji, C. (2009). Impossible Engineering: Technology and Territoriality on the Canal du Midi. Princeton: Princeton University Press.

Nagel J. K. S., Pierrakos O., Zilberberg, A. and McVay S. (2012) Understanding industry experiences: from problem solving to engineering students' learning gains. Proceedings Frontiers in Education Conference, 2012, 927 932.ASEE/IEEE

Nakamura T., Taguchi E., Hirose D., Masahiro I. , Takashima A., "Role-Play Training for Project Management Education Using a Mentor Agent" vol. 3, pp.175-180, 2011 IEEE/WIC/ACM International Conferences on Web Intelligence and Intelligent Agent Technology, 2011

National Research Council, Shavelson and Towne, L, Eds. (2002), Scientific Research in Education, Washington, DC: National Academy Press, p 70

Nielsen K. \& Heymann M., Winds of change: communication and wind power technology development in Denmark and Germany from 1973 to ca. 1985, Engineering Studies Vol. 4, Iss. 1, 2012

Passow, H. J. (2012). Which ABET competencies do engineering graduates find most important in their work?. Journal of Engineering Education, 101(1), 95.

Puerzer, R. J., \& Rooney, D. M. (2002). The alumni survey as an effective assessment tool for small engineering programs. Journal of Engineering Education, 91(1), 109.

Regan, T. M., \& Schmidt, J. A. (1999, November). Student learning outcomes: alumni, graduating seniors and incoming freshmen. In Frontiers in Education Conference, 1999. FIE'99. 29th Annual (Vol. 3, pp. 13A5-16). IEEE

Rodrigues, M de L., 1999, Os Engenheiros em Portugal, Celta Editora, Oeiras pp. 207-230

Shinn, T. (2002), The Triple Helix and New Production of Knowledge: Prepackaged Thinking on Science and Technology. Social Studies of Science, 32(4), 599-614.

Sladovich, H., Ed (1991) Engineering as a social enterprise, Washington, D.C. National Academy Press

Stevens R., Johri, A. \& O'Connor, K. (2014), Professional Engineering Work, Cambridge Handbook of Engineering Education Research, Cambridge University Press, 2014, New York, NY

Taylor, F. W., The Principles of Scientific Management, New York, NY, USA and London, UK: Harper \& Brother

Tilli, S. and J. P. Trevelyan (2008). Longitudinal Study of Australian Engineering Graduates: Preliminary Results. American Association for Engineering Education (ASEE) Annual Conference, Pittsburgh.

Trevelyan, J. P (2010) "Reconstructing engineering from practice", Engineering Studies, Volume 2, Issue 3, 2010, Special Issue: Situated Engineering in the Workplace

Trevelyan, J. P. (2013). Observations of South Asian Engineering Practice. In B. Williams, J. D. Figueiredo \& J. P. Trevelyan (Eds.), Engineering Practice in a Global Context: Approaches on Technical and Social Influences that can help Educators, Leiden, Netherlands: CRCpress/Balkema, 2013.

Trevelyan J. P., The Making of an Expert Engineer, CRCpress, Taylor \& Francis, 2014

Turner, B. T, (1969) Management Training for Engineers. London, Business Books

Venning, M. Professional Engineers, Scientists and Technologists in the Engineering Industry, EUITB Research Report no. 4, Watford, Engineering Industry Training Board

Vest D., Long M. \& Anderson T., Electrical Engineers' Perceptions of Communication Training and Their Recommendations for Curricular Change: Results of a National Survey, IEEE Transactions on Professional Communication, Vol. 39, No. 1, March 1996 
Vincenti, W. G. (1990). What Engineers Know and How They Know It: Analytical Studies from Aeronautical History. Baltimore: The Johns Hopkins University Press.

Vinck, D. (2003), Everyday Engineering: An Ethnography of Design and Innovation, Inside Technology, W.E. Bijker, W.B. Carlson, and T.J.Pinch (eds.), Boston, MA: MIT Press, 2003.

Williams B., Figueiredo J. D. \& Trevelyan J. P. (Eds.) (2013), Engineering Practice in a Global Context: Understanding the Technical and the Social, Leiden, Netherlands: CRCpress, Taylor \& Francis

Williams B., (2015) Finding Workable Solutions: Engineering Practice as a Field of Inquiry, (unpublished doctoral thesis), Instituto Superior Tecnico, Universidade de Lisboa, Portugal.

Williams, R. (2002). Retooling: a historian confronts technological change. Cambridge, Mass.: MIT Press

Youngman, M., Oxtoby, R., Monk, J. D., \& Heywood, J. (1978). Analysing Jobs. Farnborough, Hampshire, UK: Gower Press. 